\title{
PENGARUH UKM BERBASIS INOVASI TERHADAP PEREKONOMIAN DI PROVINSI JAWA TIMUR
}

Berdasarkan laporan dari Bank Indonesia pada tahun 2008, perekonomian Indonesia sedang mengalami masalah dan menerima imbas dari krisis ekonomi secara global pada saat itu. Hal tersebut ditandai dengan neraca perdagangan Indonesia pada tahun 2008-2011 yang mengalami defisit. Hal ini disebabkan oleh perbandingan jumlah ekspor dan impor antara Indonesia dengan Cina tidak seimbang. Indonesia mengimpor jauh lebih banyak daripada mengekspor barang. Berdasarkan laporan tahun 2006, peringkat daya saing berbagai produk Indonesia semakin menurun akhir-akhir ini. Salah satu penyebabnya tidak lain adalah kualitas Sumber Daya Manusia dan Teknologi yang dimiliki Indonesia kalah bersaing dengan Cina. Aktivitas perekonomian yang terus menurun akan berdampak buruk terhadap neraca perdagangan Indonesia dalam jangka panjang. Selain itu, kesenjangan sosial juga akan muncul secara tidak langsung dari aktivitas perekonomian yang turun.

Indonesia telah lama terjerat dalam permasalahan ekonomi seperti pengangguran dan kemiskinan. Masalah ini sulit dihindari karena jumlah penduduk Indonesia yang dapat dibilang tidak sedikit, khususnya di area Jawa Timur yang berjumlah 37.476.011 jiwa (Sumber: Badan Pusat Statistik 2015). Maka dari itu, untuk meminimalisir masalah tersebut diperlukan faktor pendorong yang dapat memicu perkembangan ekonomi. UKM (Usaha Kecil Menengah) adalah salah satu bentuk aktivitas yang terbukti membantu pertumbuhan ekonomi di Indonesia, khususnya daerah Jawa Timur. Meskipun taraf UKM tidak sebesar perusahaan berskala nasional, namun dengan banyaknya jumlah UKM yang ada dapat memberikan kontribusi positif dalam menstabilkan kembali neraca perdagangan Indonesia. Hal ini terlihat dari berkurangnya jumlah pengangguran dan meningkatnya PDRB (Pendapatan Domestik Regional Bruto) serta pendapatan perkapita masyarakat Jawa Timur setiap tahunnya.

UKM sendiri merupakan bentuk usaha yang banyak diminati oleh masyarakat karena tidak membutuhkan modal besar seperti usaha-usaha lain pada umumnya. Oleh karena itu, banyak masyarakat yang tertarik untuk terjun dalam bisnis UKM. Perekonomian di Jawa Timur pun didominasi oleh keberadaan UKM. Dalam perkembangannya, UKM juga ditunjang oleh adanya sumber daya alam yang heterogen serta lokasi Jawa Timur sebagai pasar strategis di pulau Jawa. Namun, UKM tidak dapat berdiri sendiri tanpa dukungan dan arahan dari pemerintah juga diperlukan dalam menunjang keberhasilan dan pertumbuhan UKM. Pemerintah dapat mengarahkan UKM untuk menciptakan produk yang efektif dan efisien sehingga dapat bersaing dengan produk dari negara lain. Selain itu, dengan memudahkan UKM untuk melakukan kredit pada bank juga merupakan bukti support pemerintah terhadap tumbuh-kembang UKM. Sisi positifnya bagi negara adalah dapat 
meningkatkan cadangan devisa negara serta keberadaan UKM lebih mudah menyerap tenaga kerja sehingga dapat mengurangi angka pengangguran.

Dalam menghadapi persaingan dengan Cina, UKM perlu menggunakan beberapa strategi berbasis inovasi. Untuk menjalankan strategi tersebut, diperlukan pengumpulan dan pengolahan data secara primer dan sekunder. Data primer bisa didapatkan melalui survey langsung ke masyarakat, sedangkan data sekunder bisa didapatkan melalui media internet. Selanjutnya, strategi pengembangan UKM dapat menggunakan analisis SWOT (Strength-Weakness, Opportunity-Threats) yang memudahkan UKM dalam berinovasi. Apabila terdapat masalah, analisis SWOT tidak hanya melihat dari satu sisi saja, namun dari empat sisi yang berbeda. Hasil analisis SWOT dapat dijadikan pedoman dalam mempertahankan Strength (Kekuatan), memanfaatkan sebaik mungkin terkait adanya Opportunity (Peluang), dan diharapkan mampu mencegah Threat (Ancaman) maupun meminimalisir Weakness (Kelemahan). Empat sisi dari analisis tersebut dapat dijelaskan sebagai berikut:

1) Strength (Kekuatan): Keseluruhan sumber daya yang dimiliki diharapkan dapat menopang jalannya UKM, seperti ketersediaan tenaga kerja yang melimpah.

2) Weakness (Kelemahan): Sesuatu yang berhubungan dengan kekurangan yang timbul dari aktivitas UKM diharapkan dapat diminimalisir, seperti keterbatasan modal dan keterbatasan penguasaan teknologi.

3) Opportunity (Peluang): Suatu kondisi yang memberikan manfaat bagi UKM, seperti dibukanya kerjasama masyarakat se-ASEAN yang dapat memudahkan UKM dalam memasarkan produknya ke pasar yang lebih luas.

4) Threat (Ancaman): Kendala atau permasalahan yang ada ketika akan memulai kegiatan UKM, baik internal maupun eksternal. Contohnya seperti kesulitan dalam menerima pengakuan akan keberadaan suatu UKM. Serta kelalaian dalam mengelola data penting terkait dengan penunjang pertumbuhan UKM.

Terlepas dari strategi berbasis inovasi diatas, kesiapan diri dalam menghadapi situasi pasar serta perencanaan yang tepat adalah hal terpenting dalam menjalankan UKM. Oleh karena itu, sebaiknya UKM harus dapat memahami kondisi pasar serta mempersiapkan perencanaan yang matang agar dapat mempertahankan keberadaan UKM serta mengambil keputusan yang tepat.

Kelebihan artikel yang ditulis oleh Bapak Ahmad Zafrullah antara lain adalah bahasa yang digunakan merupakan bahasa baku dan mudah dipahami, serta terdapat banyak data yang mendukung dalam menjelaskan isi artikel tersebut. Selain itu, artikel juga berguna untuk menambah pemahaman dan pengetahuan bagi para pembaca. Namun, kekurangannya adalah artikel ditulis pada tahun 2015 serta data-data yang digunakan merupakan data tahun 2010-2014 dimana sudah lumayan tertinggal dengan kondisi perekonomian pada tahun sekarang. 
Daftar Pustaka:

Andre Hermanto, Ahmad Zafrullah Tayibnapis, Idfi Setyaningrum, Strategi Pengembangan UKM Berbasis Inovasi di Provinsi Jawa Timur: Periode 2010-2014, Ekonomi dan Bisnis: Berkala Publikasi Gagasan Konseptual, Hasil Penelitian, Kajian, dan Terapan Teori, Vol. 20 No. 2, ISSN 1410-9204, 2016.

Irawan, A, dkk. 2007. Kewirausahaan UKM : Pemikiran dan Pengalaman : Karya Bersama FE UBAYA dan Forum Daerah UKM JATIM. Yogyakarta: Graha Ilmu.

Agustina, Tri Siwi. 2015. Kewirausahaan : Teori dan Penerapan pada Wirausaha dan UKM di Indonesia. Jakarta: Mitra Wacana Media.

Alamat Sumber DOI: https://doi.org/10.24123/jeb.v20i2.1599

Perekonomian Indonesia / KP-D

Anggota Kelompok:

David Natanael S / 130318055

Handoyo Subagio / 130318149

Cindy Lovera H / 130318152

Elizabeth Ellaine P / 130318174

Catherine Nathaniela L/ 130318261 